\title{
Poverty distribution of different types of forest-related communities: Case study in Wan Abdul Rachman Forest Park and mangrove forest in Sidodadi Village, Lampung Province, Indonesia
}

\author{
ROMMY QURNIATI ${ }^{1, \vartheta}$, ARIEF DARMAWAN ${ }^{1}$, RIZKI BAHAGIA UTAMA ${ }^{1}$, MAKOTO INOUE ${ }^{2}$ \\ ${ }^{1}$ Department of Forestry, Faculty of Agriculture, Universitas Lampung. J1 Soemantri Brojonegoro, Gedung Meneng, Bandar Lampung 35145, Lampung, \\ Indonesia. Tel.: +62-721-704946, Fax.: +62-721-770347. `email: rommy.qurniati@gmail.com. \\ ${ }^{2}$ Faculty of Human Sciences, Waseda University. Tokorozawa, 359-1192, Japan
}

Manuscript received: 24 September 2019. Revision accepted: 9 October 2019.

\begin{abstract}
Qurniati R, Darmawan A, Utama RB, Inoue M. 2019. Poverty distribution of different types of forest-related communities: Case study in Wan Abdul Rachman Forest Park and mangrove forest in Sidodadi Village, Lampung Province, Indonesia. Biodiversitas 20: 3153-3163. Forest has important role in community because it can influence social characteristics as well as the quality of life of the household. In the tropics, many people living around forest are in poor conditions. Sidodadi Village of Pesawaran District, Lampung Province bordered to Wan Abdul Rachman (WAR) Forest Park in the upland and mangrove forest in the coastal area represents a good case study of communities living adjacent to forests with different ecosystem type. The research objective was to identify and analyze the characteristics and the level of household poverty of community living around two forested areas (i.e. upland forest in WAR Forest Park versus mangrove forest) in Sidodadi Village. In this village, households were interviewed by randomly selecting 215 respondents. The poverty was analyzed using five indicators, i.e. the economic characteristics, material wealth, health, infrastructure and services, and knowledge. The study found that base on the aggregated five poverty indicators there were no households categorized as poor. However, analyses in each indicator had diverse results. Based on the indicators of knowledge and economic characteristics, we found that most respondents were classified as poor while based on three other indicators there were classified as rich. The poor knowledge level was dominantly in older people who have low formal and informal education, while poverty in terms of economic characteristics due to limited opportunity to have better livelihood. Results also indicate that the poor households were located near mangrove forests while those classified as rich were located near upland forest in WAR Forest Park. The rich households had better opportunities to earn income from limited uses of forest in the upland area, yet similar opportunities were not obtained from mangrove forests. Sustainable use of mangrove forests should be considered to support the livelihood option of the surrounding community to enhance their wealth.
\end{abstract}

Keywords: Economic characteristics, health, infrastructure and services, knowledge, material wealth

\section{INTRODUCTION}

The societies in Southeast Asian countries are loosely structured and each area had its unique attributes (Takata and Inoue 2017). This loosely structured in society allows individual behavior to be varied socio-culturally than in a more rigid structure (Embree 1950). The behavioral variation is the result of adaptation in the humanenvironment system in response to observed or expected changes (Shikuku et al. 2017) that can lead differences in attribute of community between regions. The attributes of community are influenced by a variety of factors, including historical background, biophysical conditions, sociocultural and economic characteristics, in which these factors are explained in Budiharta et al. (2016) study as a socio-ecological system. In Indonesia, the socio-ecological conditions of rural communities are diverse (Withaningsih et al. 2019). This difference has implications on the treatments needed to overcome problems in community particularly problems related to poverty in which it consistently becomes one of the problems faced by many countries of the world (Wu et al. 2019).
Poverty is a condition that involves the inability to meet the minimum demands of life, especially from the aspect of consumption and income (Jacobus et al. 2018). Poverty can also be defined as a condition where a person or group of people who have low living standards are unable to fulfill their basic rights such as food and non-food (Pratama 2014; Mussadun and Nurpratiwi 2016) and do not have the ability, freedom, assets and access to public service facilities, the opportunity to have a business and work, and vulnerable to the risk of disease (Pratama 2014).

Most of poor communities are located adjacent to forests and in rural areas that have limited access to various resources (Syaf et al. 2013; Manwa and Manwa 2014; Nasution et al. 2015; Corral et al. 2017). These limitations can have consequences to the community on the way they struggle to fulfill livelihood. As in the communities who live around the forest, they are dependent on forest for their resources of income (Newton et al. 2016; Zada et al. 2019) because forest provides various products that can support the livelihoods of rural communities (Achmad and Diniyati 2018). 
The issues of poverty alleviation and deforestation/ forest degradation are both central in current international agenda (Angelsen and Wunder 2003). Poverty can lead to forest loss, and subsequently, forest loss might contribute to either a decrease or an increase in poverty. Therefore, there is a growing concept that economic development and poverty reduction can improve forest conditions and vice versa in which the management of forest resources can serve as essential vehicle for poverty reduction. Santika et al. (2019) found that the benefits of forest conservation and poverty alleviation systematically differed, for example when forest provides the greatest improvements in well-being, the conservation benefits are not necessarily gained. As some studies indicated that the state of forests is as much as threatened by wellbeing and by poverty (Angelsen 1997; Angelsen and Wunder 2003; Cheng et al. 2017; Santika et al. 2019).

In the tropics of Southeast Asian region, studies to identify the distribution of poverty at household level differentiated based on forest type have been limited. This study aimed to identify the poverty characteristic in a village namely Sidodadi in Lampung Province which is located between upland forest in Wan Abdul Rahman (WAR) Forest Park (Taman Hutan Raya/Tahura) and mangrove forest in Lampung Bay. This village represents a good case study because it is located in the middle of two forest ecosystems in which both forests influenced the community (Andrianto et al. 2016). Most of the households living in Sidodadi are fishermen and farmers with low levels of livelihood (Amir et al. 2013; Andrianto et al. 2016), providing excellent comparison between two forestrelated livelihood strategies (i.e. upland forest versus mangrove forest).

\section{MATERIALS AND METHODS}

\section{Study period and area}

This research was conducted from January to March 2017 in Sidodadi Village, Teluk Pandan Subdistrict, Pesawaran District, Lampung Province, Indonesia (Figure 1). The village has a wide range of landscapes, from upstream area in the mountains of WAR Forest Park to the downstream region which is directly adjacent to mangrove forest in Lampung Bay. The village is in proximity to the provincial capital (approximately $20 \mathrm{~km}$ ).

Sidodadi Village consists of four hamlets: Hamlet 1, Hamlet 2, Hamlet 3, and Hamlet 4. Hamlet 1 was directly adjacent to the mangrove forest and Hamlet 4 was directly adjacent to the WAR Forest Park. Hamlets 2 and 3 were located between the two hamlets. The number of households living in the four hamlets was 584 households. Based on this number, the number of samples (respondents) was determined using the Slovin formula and the results were 215 households. This number was proportionately assigned to four hamlets which are described in Table 1. The respondents of household were selected by systematic random sampling.
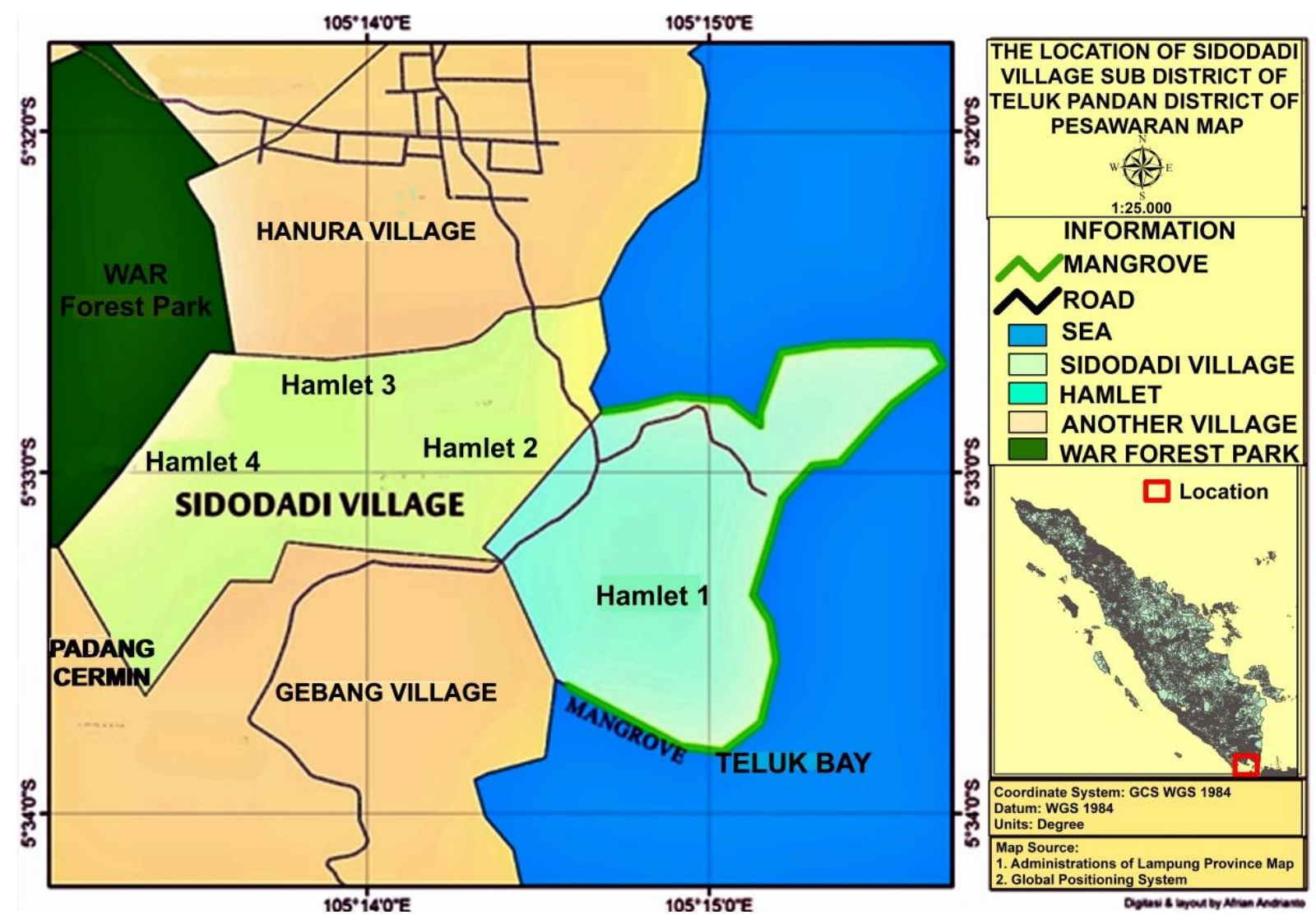

Figure 1. The study area in Sidodadi Village, Teluk Pandan Subdistrict, Pesawaran District, Lampung Province, Indonesia 
Primary data collection was carried out by household surveys, in-depth interviews, direct observation, and Focus Group Discussion (FGD). Secondary data was collected using literature studies and collection of spatial data such as maps, satellite imagery and location coordinate data (using GPS) managed in spatial databases using Geographic Information Systems (GIS).

Based on several definitions of poverty, the poverty indicators used in this study were the economic characteristics, material wealth, health, infrastructure and services, and knowledge. These indicators were described using poverty criteria adapted from Cahyat et al. (2007) and described in Table 2.

The poverty level of the household was measured using scoring technique. The wealth/poverty indicator was categorized into three classes by giving score 1 for low, 2 for medium, and 3 for high. The scores were then aggregated to calculate the index value and a threshold was applied to determine wealth/poverty level of the household. The index value was calculated in two stages.

Table 1. Household sample in Sidodadi Village, Teluk Pandan Subdistrict, Pesawaran District, Lampung Province, Indonesia

\begin{tabular}{lcc}
\hline $\begin{array}{c}\text { Hamlets (dusun) } \\
\text { in the village }\end{array}$ & $\begin{array}{c}\text { Population number } \\
\text { (households) }\end{array}$ & Sample number \\
\hline Hamlet 1 & 210 & $56(26 \%)$ \\
Hamlet 2 & 120 & $66(31 \%)$ \\
Hamlet 3 & 125 & $59(27 \%)$ \\
Hamlet 4 & 129 & $34(16 \%)$ \\
Total & 584 & $215(100 \%)$ \\
\hline
\end{tabular}

Table 2. The criteria for wealth (poverty) indicator in Sidodadi Village, Teluk Pandan Subdistrict, Pesawaran District, Lampung Province, Indonesia

\begin{tabular}{|c|c|c|c|}
\hline \multirow{2}{*}{ Criteria indicator } & \multicolumn{3}{|c|}{ Levels } \\
\hline & Low & Medium & High \\
\hline \multicolumn{4}{|l|}{ Economic characteristics } \\
\hline Number of sources of income & One & - & More than one \\
\hline Fixed income & None & - & Minimum one \\
\hline Access to clean water & No access & Sometimes have access & Always have access \\
\hline Lack of food & Sometime & - & Never \\
\hline Ability to buy rice & Unable & Able but sometimes difficult & Able \\
\hline Rice stock for several months & Never have stock & Sometimes have stock & Always have stock \\
\hline Access rice aid & No access & Sometimes have access & Always have access \\
\hline \multicolumn{4}{|l|}{ Material wealth } \\
\hline Condition of the house & $\begin{array}{l}\text { Soil floor, the wall from } \\
\text { wood or bamboo, and roof } \\
\text { from clay tile or tin roofs. }\end{array}$ & $\begin{array}{l}\text { Cement floor, the wall from brick } \\
\text { without plaster or brick and } \\
\text { plaster, and roof from clay tile. }\end{array}$ & $\begin{array}{l}\text { Ceramic floor tile, the wall } \\
\text { from brick and plaster, and } \\
\text { roof from clay roof. }\end{array}$ \\
\hline Ownership of means of transportation & No & - & Yes \\
\hline Ownership of home appliances & No & - & Yes \\
\hline Ownership of communication tools & No & - & Yes \\
\hline \multicolumn{4}{|l|}{ Health } \\
\hline Access to health services & No access & Sometimes have access & Always have access \\
\hline Access to health care & No access & Sometimes have access & Always have access \\
\hline Quality of health services & Bad & Good & Very good \\
\hline Access health insurance & Bad & Good & Very good \\
\hline \multicolumn{4}{|l|}{ Knowledge } \\
\hline $\begin{array}{l}\text { Highest education level of family } \\
\text { members }\end{array}$ & Elementary school & Junior High School & $\begin{array}{l}\text { Senior High School and } \\
\text { more high level }\end{array}$ \\
\hline Highest education level of wife & Elementary school & Junior High School & $\begin{array}{l}\text { Senior High School and } \\
\text { more high level }\end{array}$ \\
\hline Non-formal education of husband & None & - & Have \\
\hline Non-formal education of wife & None & - & Have \\
\hline Education of children ( $7-17$ years old) & No one gets to school & Only some get to school (not all) & All get school \\
\hline Access to Junior High School & Unable & Able but difficult & Able and easy \\
\hline Access to scholarships & No access & Have access but difficult & Have access \\
\hline Additional skills for family member & None & One & More than one \\
\hline \multicolumn{4}{|l|}{ Infrastructure and services } \\
\hline Quality of roads and bridges & Bad & Good & Very good \\
\hline Access to markets & Far & Moderate & Near \\
\hline Access to business credit & No access & Have access but difficult & Have access \\
\hline Access to poor relief of housing & No access & - & Have access \\
\hline Access to spiritual activity & No access & Sometimes have access & Always have access \\
\hline Facilities of sport and recreation & Bad & Good & Very good \\
\hline
\end{tabular}


The first stage was the calculation of five primary indicators as described in Table 2. To calculate the indices, the range of values at each index needs to be known. The range of values was the lowest and highest value for each indicator in the index. The formula to calculate the indices was adapted from Cahyat et al. (2007), and expressed as follow:

Economic chracteristic index $=\frac{\text { Sum of scores obtined }- \text { Sum of minimun scores }}{\text { Sum of maximum scores }- \text { Sum of minimum scores }} \times 100$

The index value was used to determine the threshold of household wealth/poverty by using three classifications: poor, moderate, and rich. The threshold in each classification was the minimum and maximum score. The total range scores were 0 until 100. The minimum score of poor was 0 and the maximum was the score of index value. The minimum score in moderate was 1 score above the maximum score of poor and the maximum was 100 subtract the index value. The minimum score of rich was 1 score above the maximum level of moderate and the maximum was 100 . The index values and the range of scores of the five primary indicators were presented in Table 3.

In the second stage, a composite index was calculated. The index was a score value for the threshold of household wealth/poverty obtained by calculating the average of the five primary indices produced in the first stage. In the same way as calculating the threshold of the five primary indices, a range of score values for the poor, moderate, and rich classification of household wealth/poverty was obtained. Furthermore, the distribution of household wealth/poverty was recognized by tagging the Global Positioning System, positioned at every population of the villagers' house which was selected as a sample.

Table 3. Index values and range scores on the basic indicator of wealth/poverty in Sidodadi Village, Pesawaran, Lampung, Indonesia

\begin{tabular}{lcccc}
\hline \multicolumn{1}{c}{ Indicator } & $\begin{array}{c}\text { Index } \\
\text { value }\end{array}$ & Poor & Moderate & Rich \\
\hline Economic characteristic & 41 & $0-41$ & $42-59$ & $60-100$ \\
Material wealth & 42 & $0-42$ & $43-58$ & $59-100$ \\
Health & 37 & $0-37$ & $38-63$ & $64-100$ \\
Infrastructure and services & 42 & $0-42$ & $43-58$ & $59-100$ \\
Knowledge & 36 & $0-36$ & $37-64$ & $65-100$ \\
\hline
\end{tabular}

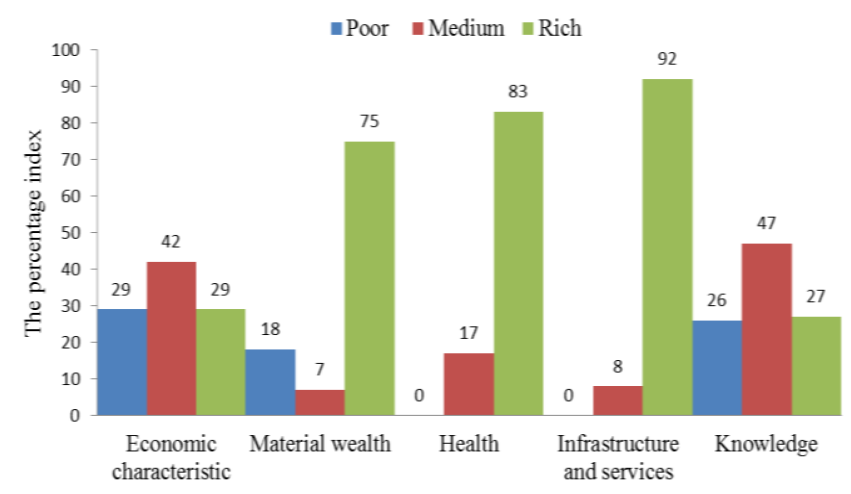

Figure 2. The percentage index of household wealth/poverty in Sidodadi Village, Pesawaran District, Lampung, Indonesia

\section{RESULTS AND DISCUSSION}

\section{Household wealth/poverty}

Poverty is a condition that is emblematic to the people who live around the forest. It is a situation where a person or household has difficulty meeting basic needs, while the supporting environment lacks opportunities to improve welfare sustainably or out of vulnerability. Based on the five indicators of the poverty used in this study, no household in the studied area was classified as poor (Figure 2 ). As indicated by the large proportion of the material wealth, health and infrastructure and services index, these were classified as rich. On the other hand, the indicator of economic characteristics and knowledge were at medium level.

\section{Economic characteristics}

The number of sources of income and the existence of fixed income illustrates the long-term stability of household income. The fixed income of a household provides a sense of security in fulfilling its needs at least for primary consumption. When supported by other sources of income, it can reduce the vulnerability of dependence on a single source of income. The result of this study suggested that the number of source of income for households in Sidodadi is limited (Table 4). Generally, people who live adjacent to mangrove forests only had one source of income as fishermen and people who live adjacent to WAR Forest Park worked as farmer. Although the income of farmers and fishermen can be categorized as fixed income, the amount of income varied each month. The income of farmers and fishermen was influenced by the condition of natural environment. When the weather was bad, the yield will decrease or fail. This income was only able to fulfil basic needs which in this study were measured by the ability to get rice and clean water.

The community in Sidodadi did not have many choices of income sources because of limited financial capital and skills. Limited skills are also explained in the study of Machmud et al. (2019) as a factor influencing community poverty on the Lake Limboto Coast. In addition, Qurniati et al. (2017a) explained the limitation of alternative income for people who live around the forest due to the lower level of education which forced them to work as on-farm laborers. On-farm laborers in Sidodadi became the main option to have additional income for people who had not financial and human capital. This is in line with the study of Simarmata et al. (2018) who found that on-farm laborers are sided jobs done by farmers to supplement income because land yields are considered to be insufficient for household needs.

Communities classified as poor if they are unable to meet their basic needs such as food and non-food therefore economic factors become early indicators in determining poverty. This study measured the adequacy of food-based ability to meet the needs of rice as the staple food. The community in Sidodadi did not suffer from the lack of staple food, but because of limited economic capacity, rice was purchased for a few days only. There was no saving of rice for the needs of weeks or one month as rich households. Social aid in the form of rice for the poor was 
received by all residents of Sidodadi. Whereas rice aid is intended by the Indonesian government for the poor, but in its implementation, the rice was distributed equally to all households in Sidodadi, including the rich. As a result, the amount of rice received by the poor is not sufficient.

Access to clean water is not only measured by access or ownership of well water. The emphasis on this research was on the ability to get clean water either from private water sources (wells), village water sources (public common) or buy clean water. Rich households were always able to meet clean water needs for their families.

Clean water became an obstacle for the coastal community like Sidodadi particularly for Hamlet 1 . People who lived in coastal areas generally had problems with clean water because wells that were close to the beach produced brackish water so it cannot be used as drinking water. The declining area of mangrove forests in Sidodadi (Nugraha et al. 2015) affects the quality of fine water because mangrove forest serves to decrease the salinity of water (Tiara et al. 2017). The low water quality was not used by the community for drinking and cooking. This condition burdened household income because they had to buy clean water for their daily needs. This finding is in line with the poverty profile that occurs on the island of Lombok, difficulties in accessing clean water are a heavy burden for the poor (Suryani et al. 2019).

\section{Material wealth}

Material wealth is generally indicated by the quality of the house and home appliances, as described in Table 5.
House conditions such as walls, floors, and roofs are the indicators of home standards. A household with house that has permanent walls, tile floors, and tile roofs is categorized as above standard or rich. Conversely, if the house is made of brick walls, wood, or geribik (a wall made of bamboo matting) with rough cement or soil floors is categorized as below standard or poor household. Some poor households in Sidodadi which did not own a house were generally young couples who had recently been married, but the number is not many. They lived with their parents or stay in other people homes that unoccupied. A household is classified as medium of if their house is between the two aforementioned conditions.

When the need for a place to live (i.e. home) has been fulfilled then welfare will be realized in the ownership of material wealth that can facilitate daily activities and improve convenience. Fulfillment depends on the ability and level of needs. Motorcycle is material wealth that was almost owned by all households although it varied in quantity and quality. People can purchase a new or secondhand motorcycle by credit with low down payments and installments. Rich households even had several motorcycles to facilitate the mobility of all family members, particularly if they had children who needed transportation to school, because village transport was only connected among villages without a pass-through hamlet road. Therefore motorcycles had become the primary transportation tool for mobility in the village beside a good road that also supported the use of it.

Table 4. Economic characteristics in Sidodadi Village, Teluk Pandan Subdistrict, Pesawaran District, Lampung Province, Indonesia

\begin{tabular}{|c|c|c|c|c|c|}
\hline \multirow{2}{*}{ Poverty indicator } & \multirow{2}{*}{ Household wealth category } & \multicolumn{3}{|c|}{ Wealth/poverty indicator } & \multirow{2}{*}{ Total } \\
\hline & & Low & Medium & High & \\
\hline \multirow[t]{4}{*}{ Number of sources of income } & Poor & $52(85 \%)$ & $0(0 \%)$ & $9(15 \%)$ & $61(29 \%)$ \\
\hline & Moderate & $76(84 \%)$ & $0(0 \%)$ & $14(16 \%)$ & $90(42 \%)$ \\
\hline & Rich & $23(37 \%)$ & $0(0 \%)$ & $40(63 \%)$ & $63(29 \%)$ \\
\hline & Whole & $151(71 \%)$ & $0(0 \%)$ & $63(29 \%)$ & $214(100 \%)$ \\
\hline \multirow[t]{4}{*}{ Fixed income } & Poor & $35(57 \%)$ & $0(0 \%)$ & $26(43 \%)$ & $61(29 \%)$ \\
\hline & Moderate & $19(21 \%)$ & $0(0 \%)$ & $71(79 \%)$ & $90(42 \%)$ \\
\hline & Rich & $6(10 \%)$ & $0(0 \%)$ & $57(90 \%)$ & $63(29 \%)$ \\
\hline & Whole & $60(28 \%)$ & $0(0 \%)$ & $154(72 \%)$ & $214(100 \%)$ \\
\hline \multirow[t]{4}{*}{ Access to clean water } & Poor & $7(11 \%)$ & $13(21 \%)$ & $42(68 \%)$ & $61(29 \%)$ \\
\hline & Moderate & $5(6 \%)$ & $5(6 \%)$ & $80(89 \%)$ & $90(42 \%)$ \\
\hline & Rich & $2(3 \%)$ & $2(3 \%)$ & $59(94 \%)$ & $63(29 \%)$ \\
\hline & Whole & $14(7 \%)$ & $20(9 \%)$ & $181(84 \%)$ & $214(100 \%)$ \\
\hline \multirow[t]{4}{*}{ Lack of food } & Poor & $51(82 \%)$ & $0(0 \%)$ & $11(18 \%)$ & $61(29 \%)$ \\
\hline & Moderate & $28(31 \%)$ & $0(0 \%)$ & $62(69 \%)$ & $90(42 \%)$ \\
\hline & Rich & $3(5 \%)$ & $0(0 \%)$ & $60(95 \%)$ & $63(29 \%)$ \\
\hline & Whole & $82(38 \%)$ & $0(0 \%)$ & $133(62 \%)$ & $214(100 \%)$ \\
\hline \multirow[t]{4}{*}{ Ability to buy rice } & Poor & $5(9 \%)$ & $41(72 \%)$ & $11(19 \%)$ & $57(27 \%)$ \\
\hline & Moderate & $2(2 \%)$ & $28(31 \%)$ & $59(66 \%)$ & $89(43 \%)$ \\
\hline & Rich & $0(0 \%)$ & $10(16 \%)$ & $53(84 \%)$ & $63(30 \%)$ \\
\hline & Whole & $7(3 \%)$ & $7938 \%)$ & $123(59 \%)$ & $209(100 \%)$ \\
\hline \multirow[t]{4}{*}{ Rice stock for several months } & Poor & $50(86 \%)$ & $7(12 \%)$ & $1(2 \%)$ & $58(28 \%)$ \\
\hline & Moderate & $73(82 \%)$ & $11(12 \%)$ & $5(6 \%)$ & $89(42 \%)$ \\
\hline & Rich & $36(57 \%)$ & $9(14 \%)$ & $18(29 \%)$ & $63(30 \%)$ \\
\hline & Whole & $159(76 \%)$ & $27(13 \%)$ & $2411 \%)$ & $210(100 \%)$ \\
\hline \multirow[t]{4}{*}{ Access rice aid } & Poor & $54(89 \%)$ & $6(10 \%)$ & $1(2 \%)$ & $61(29 \%)$ \\
\hline & Moderate & $66(74 \%)$ & $17(19 \%)$ & $6(7 \%)$ & $90(42 \%)$ \\
\hline & Rich & $21(33 \%)$ & $23(37 \%)$ & $19(30 \%)$ & $63(30 \%)$ \\
\hline & Whole & $141(66 \%)$ & $46(22 \%)$ & $26(12 \%)$ & $214(100 \%)$ \\
\hline
\end{tabular}


Table 5. Material wealth in Sidodadi Village, Teluk Pandan Subdistrict, Pesawaran District, Lampung Province, Indonesia

\begin{tabular}{|c|c|c|c|c|c|}
\hline \multirow{2}{*}{ Poverty indicator } & \multirow{2}{*}{ Household wealth category } & \multicolumn{3}{|c|}{ Wealth/poverty indicator } & \multirow{2}{*}{ Total } \\
\hline & & Low & Medium & High & \\
\hline \multirow[t]{4}{*}{ The condition of the house } & Poor & $18(49 \%)$ & $19(51 \%)$ & $0(0 \%)$ & $37(17 \%)$ \\
\hline & Moderate & $14(88 \%)$ & $2(13 \%)$ & $0(0 \%)$ & $16(7 \%)$ \\
\hline & Rich & $7(4 \%)$ & $35(22 \%)$ & $119(74 \%)$ & $161(75 \%)$ \\
\hline & Whole & $39(18 \%)$ & $56(26 \%)$ & $119(56 \%)$ & $214(100 \%)$ \\
\hline \multirow[t]{4}{*}{ Ownership of means of transportation } & Poor & $27(73 \%)$ & $0(0 \%)$ & $10(27 \%)$ & $37(17 \%)$ \\
\hline & Moderate & $1(6 \%)$ & $0(0 \%)$ & $15(94 \%)$ & $16(7 \%)$ \\
\hline & Rich & $40(35 \%)$ & $0(0 \%)$ & $121(75 \%)$ & $161(75 \%)$ \\
\hline & Whole & $68(32 \%)$ & $0(0 \%)$ & $146(68 \%)$ & $214(100 \%)$ \\
\hline \multirow[t]{4}{*}{ Ownership of home appliances } & Poor & $31(82 \%)$ & $0(0 \%)$ & $7(18 \%)$ & $38(18 \%)$ \\
\hline & Moderate & $15(94 \%)$ & $0(0 \%)$ & $1(6 \%)$ & $16(7 \%)$ \\
\hline & Rich & $3(2 \%)$ & $0(0 \%)$ & $158(98 \%)$ & $161(75 \%)$ \\
\hline & Whole & $49(23 \%)$ & $0(0 \%)$ & $166(77 \%)$ & $215(100 \%)$ \\
\hline \multirow[t]{4}{*}{ Ownership of communication tools } & Poor & $8(22 \%)$ & $12(33 \%)$ & $16(44 \%)$ & $36(17 \%)$ \\
\hline & Moderate & $0(0 \%)$ & $2(13 \%)$ & $14(88 \%)$ & $16(8 \%)$ \\
\hline & Rich & $19(12 \%)$ & $67(42 \%)$ & $75(47 \%)$ & $161(76 \%)$ \\
\hline & Whole & $27(13 \%)$ & $81(38 \%)$ & $105(49 \%)$ & $213(100 \%)$ \\
\hline
\end{tabular}

Communication tools and home appliances that most owned by Sidodadi community were cellular phones and television. The use of cellular phones had been increasing rapidly over the past few years so that the information channel had become easier. Cellular phones that were used to be expensive luxury goods were available in a variety of prices, so it was widely used not only by rich households but also the poor ones. In addition to communication tools, television was widely owned by people in the village to meet their information and entertainment needs, although the televisions varied in size and quality. The televisions owned by the poor were generally small and of low quality, while the rich had bigger and high quality. The ease of information both through communication tools and television can make individuals will be interconnected and influence each other.

\section{Health}

Good infrastructure and quality of service are essential in reducing village poverty. People living in a supportive environment will be much more prosperous because their needs can be met easily. Healthy becomes expensive when sick people are difficult to get health service and it becomes burden for poor people. Table 6 shows that people in Sidodadi had good access to health, especially access to medical services from bidan desa (medical assistance) and community health centers. Health indicators were good because of public health insurance from the government. This program was responded well to the community, especially the poor. This program can overcome the obstacles and constraints faced by the poor for health services and to improve the health status of the poor.

The community in Sidodadi had good access to public health services; not only in the form of modern medical services but also in traditional services (dukun, tukang urut, etc.). In certain types of diseases or health problems, the village community preferred to go to a dukun, and tukang urut (the traditional massager) compared to modern health center, especially for older people who were still strongly influenced by hereditary traditions. Dukun is a term for person who has supernatural abilities to understand things that are invisible and able to communicate with spirits and supernatural realms, which are used to help solve problems or diseases. Also, there is a dukun bayi, a person who helps the childbirth process and takes care of the baby with various special spells and skills learned from their predecessors. To reduce maternal and child mortality during childbirth, especially in the village, doctors and medical assistants conducted counseling and collaboration with dukun bayi as partners so that the quality of traditional health services can be improved.

\section{Transportation and services}

Sidodadi had good infrastructure and services (Table 7). Road access provides new opportunities for increasing income and rural development (Spey et al. 2019). Good access to goods and outreach to the market could meet both the needs of public consumption and marketing of agricultural and fishery products. Unfortunately, agriculture and fishery products that were marketed were not processed into products that can provide value-added to the community. Meanwhile, the businesses of agriculture and fishery had a high risk, characterized by fluctuations in production that sometimes cannot be predicted because it depends on natural conditions. Limited knowledge and skills about agricultural and fishery products were caused by the low level of formal and non-formal education of the community.

Lin et al's (2019) study in rural China provided result that the business credit in rural areas can improve the welfare of poor households. In Sidodadi, business credit offered by the government and the private sector had been widely known by the community. However, many households were not interested because they required collateral in the form of land and building certificates to obtain it. This guarantee was generally not owned by the community. The types of loans that did not use collateral can be obtained through loan sharks, but the loan interest was very high, so these loans were not used for business purposes but for urgent needs. 
Table 6. Health in Sidodadi Village, Teluk Pandan Subdistrict, Pesawaran District, Lampung Province, Indonesia

\begin{tabular}{|c|c|c|c|c|c|}
\hline \multirow{2}{*}{ Poverty indicator } & \multirow{2}{*}{ Household wealth category } & \multicolumn{3}{|c|}{ Wealth/poverty indicator } & \multirow{2}{*}{ Total } \\
\hline & & Low & Medium & High & \\
\hline \multirow{4}{*}{ Access to health services } & Poor & $0(0 \%)$ & $0(0 \%)$ & $0(0 \%)$ & $0(0 \%)$ \\
\hline & Moderate & $4(11 \%)$ & $12(33 \%)$ & $20(56 \%)$ & $36(17 \%)$ \\
\hline & Rich & $3(2 \%)$ & $7(4 \%)$ & $169(94 \%)$ & $179(83 \%)$ \\
\hline & Whole & $7(3 \%)$ & $19(9 \%)$ & $189(88 \%)$ & $215(100 \%)$ \\
\hline \multirow[t]{4}{*}{ Access to health care } & Poor & $0(0 \%)$ & $0(0 \%)$ & $0(0 \%)$ & $0(0 \%)$ \\
\hline & Moderate & $0(0 \%)$ & $19(53 \%)$ & $17(47 \%)$ & $36(17 \%)$ \\
\hline & Rich & $0(0 \%)$ & $16(9 \%)$ & $163(91 \%)$ & $179(83 \%)$ \\
\hline & Whole & $0(0 \%)$ & $35(16 \%)$ & $180(84 \%)$ & $215(100 \%)$ \\
\hline \multirow[t]{4}{*}{ Quality of health services } & Poor & $0(0 \%)$ & $0(0 \%)$ & $0(0 \%)$ & $0(0 \%)$ \\
\hline & Moderate & $7(19 \%)$ & $12(33 \%)$ & $17(47 \%)$ & $36(17 \%)$ \\
\hline & Rich & $1(1 \%)$ & $13(7 \%)$ & $165(92 \%)$ & $179(83 \%)$ \\
\hline & Whole & $8(4 \%)$ & $25(12 \%)$ & $182(85 \%)$ & $215(100 \%)$ \\
\hline \multirow{4}{*}{ Access health insurance } & Poor & $0(0 \%)$ & $0(0 \%)$ & $0(0 \%)$ & $0(0 \%)$ \\
\hline & Moderate & $31(86 \%)$ & $0(0 \%)$ & $5(14 \%)$ & $36(17 \%)$ \\
\hline & Rich & $42(23 \%)$ & $0(0 \%)$ & $137(77 \%)$ & $179(83 \%)$ \\
\hline & Whole & $73(73 \%)$ & $0(0 \%)$ & $142(66 \%)$ & $215(100 \%)$ \\
\hline
\end{tabular}

Table 7. Infrastructure and services in Sidodadi Village, Teluk Pandan Subdistrict, Pesawaran District, Lampung Province, Indonesia

\begin{tabular}{|c|c|c|c|c|c|}
\hline \multirow{2}{*}{ Poverty indicator } & \multirow{2}{*}{ Household wealth category } & \multicolumn{3}{|c|}{ Wealth/poverty indicator } & \multirow{2}{*}{ Total } \\
\hline & & Low & Medium & High & \\
\hline \multirow[t]{4}{*}{ Quality of roads and bridges } & Poor & $1(100 \%)$ & $0(0 \%)$ & $0(0 \%)$ & $1(0 \%)$ \\
\hline & Moderate & $1(6 \%)$ & $10(59 \%)$ & $6(35 \%)$ & $17(8 \%)$ \\
\hline & Rich & $2(1 \%)$ & $45(23 \%)$ & $150(76 \%)$ & $197(92 \%)$ \\
\hline & Whole & $4(2 \%)$ & $55(26 \%)$ & $156(73 \%)$ & $215(100 \%)$ \\
\hline \multirow[t]{4}{*}{ Access to markets } & Poor & $0(0 \%)$ & $1(100 \%)$ & $0(0 \%)$ & $1(0 \%)$ \\
\hline & Moderate & $4(24 \%)$ & $8(47 \%)$ & $5(29 \%)$ & $17(8 \%)$ \\
\hline & Rich & $8(4 \%)$ & $45(23 \%)$ & $144(73 \%)$ & $197(92 \%)$ \\
\hline & Whole & $12(6 \%)$ & $54(25 \%)$ & $149(69 \%)$ & $215(100 \%)$ \\
\hline \multirow[t]{4}{*}{ Access to business credit } & Poor & $1(100 \%)$ & $0(0 \%)$ & $0(0 \%)$ & $1(0 \%)$ \\
\hline & Moderate & $9(60 \%)$ & $3(20 \%)$ & $3(20 \%)$ & $15(7 \%)$ \\
\hline & Rich & $8(4 \%)$ & $8(4 \%)$ & $181(92 \%)$ & $197(92 \%)$ \\
\hline & Whole & $18(8 \%)$ & $11(5 \%)$ & $184(86 \%)$ & $213(100 \%)$ \\
\hline \multirow[t]{4}{*}{ Access to the poor relief of housing } & Poor & $1(100 \%)$ & $0(0 \%)$ & $0(0 \%)$ & $1(0 \%)$ \\
\hline & Moderate & $13(81 \%)$ & $0(0 \%)$ & $3(19 \%)$ & $16(7 \%)$ \\
\hline & Rich & $170(86 \%)$ & $0(0 \%)$ & $27(14 \%)$ & $197(92 \%)$ \\
\hline & Whole & $184(86 \%)$ & $0(0 \%)$ & $31(14 \%)$ & $214(100 \%)$ \\
\hline \multirow[t]{4}{*}{ Access to spiritual activity } & Poor & $0(0 \%)$ & $0(0 \%)$ & $1(100 \%)$ & $1(0 \%)$ \\
\hline & Moderate & $1(6 \%)$ & $0(0 \%)$ & $16(94 \%)$ & $17(8 \%)$ \\
\hline & Rich & $0(0 \%)$ & $0(0 \%)$ & $197(100 \%)$ & $197(92 \%)$ \\
\hline & Whole & $1(0 \%)$ & $0(0 \%)$ & $214(100 \%)$ & $215(100 \%)$ \\
\hline \multirow[t]{4}{*}{ Facilities of sport and recreation } & Poor & $0(0 \%)$ & $0(0 \%)$ & $1(100 \%)$ & $1(0 \%)$ \\
\hline & Moderate & $0(0 \%)$ & $0(0 \%)$ & $17(100 \%)$ & $17(8 \%)$ \\
\hline & Rich & $0(0 \%)$ & $0(0 \%)$ & $197(100 \%)$ & $19792 \%)$ \\
\hline & Whole & $0(0 \%)$ & $0(0 \%)$ & $215(100 \%)$ & $215(100 \%)$ \\
\hline
\end{tabular}

\section{Knowledge}

Poor households have a low level of education. The formal education level did not meet the Indonesia Government program in which obligatory to have a minimum nine years of formal education (i.e. until junior high school) as seen in Table 8. The low level of education was dominated by parents or household heads, with low formal and non-formal education. In contrast to rich households, they generally had high formal and non-formal education not only for their children but also their parents.

The low education of poor households caused the lack of opportunities to get the proper jobs in increasing the welfare (Fadlillah 2016), and had an amplified impact on net household income (Panda 2015). Education can indirectly influence the household's mindset, the higher the education, the higher the motivation seen in behavior to achieve a certain level of income (Kaplale 2012). Education factor could cut off the chain of poverty since it could increase the life quality and make the household welfare achieved. The low education would affect the household in achieving good jobs to increase household welfare. It also explained in Johnson et al.'s (2016) research that found the lack of access to education and employment which could enhance livelihood options and welfare benefits pose the key drivers of poverty. 
Table 8. Knowledge in Sidodadi Village, Teluk Pandan Subdistrict, Pesawaran District, Lampung Province, Indonesia

\begin{tabular}{|c|c|c|c|c|c|}
\hline \multirow{2}{*}{ Poverty indicator } & \multirow{2}{*}{ Household wealth category } & \multicolumn{3}{|c|}{ Wealth/poverty indicator } & \multirow{2}{*}{ Total } \\
\hline & & Low & Medium & High & \\
\hline \multirow[t]{4}{*}{ Highest education of family members } & Poor & $47(84 \%)$ & $7(13 \%)$ & $2(4 \%)$ & $56(26 \%)$ \\
\hline & Moderate & $53(52 \%)$ & $27(25 \%)$ & $22(22 \%)$ & $102(47 \%)$ \\
\hline & Rich & $7(12 \%)$ & $14(25 \%)$ & $36(63 \%)$ & $57(27 \%)$ \\
\hline & Whole & $107(50 \%)$ & $48(22 \%)$ & $60(28 \%)$ & $215(100 \%)$ \\
\hline \multirow[t]{4}{*}{ Non-formal education of husband } & Poor & $49(88 \%)$ & $0(0 \%)$ & $7(13 \%)$ & $56(26 \%)$ \\
\hline & Moderate & $45(44 \%)$ & $0(0 \%)$ & $57(56 \%)$ & $102(47 \%)$ \\
\hline & Rich & $2(4 \%)$ & $0(0 \%)$ & $55(96 \%)$ & $57(27 \%)$ \\
\hline & Whole & $96(45 \%)$ & $0(0 \%)$ & $119(55 \%)$ & $215(100 \%)$ \\
\hline \multirow[t]{4}{*}{ Education of children (7-17 years old) } & Poor & $19(34 \%)$ & $16(29 \%)$ & $21(38 \%)$ & $56(26 \%)$ \\
\hline & Moderate & $4(4 \%)$ & $28(27 \%)$ & $70(69 \%)$ & $102(47 \%)$ \\
\hline & Rich & $0(0 \%)$ & $6(11 \%)$ & $51(89 \%)$ & $57(27 \%)$ \\
\hline & Whole & $23(11 \%)$ & $50(23 \%)$ & $142(66 \%)$ & $215(100 \%)$ \\
\hline \multirow[t]{4}{*}{ Access to Junior High School } & Poor & $1(2 \%)$ & $11(20 \%)$ & $44(79 \%)$ & $56(26 \%)$ \\
\hline & Moderate & $1(1 \%)$ & $13(13 \%)$ & $88(86 \%)$ & $102(47 \%)$ \\
\hline & Rich & $0(0 \%)$ & $2(4 \%)$ & $55(96 \%)$ & $57(27 \%)$ \\
\hline & Whole & $2(1 \%)$ & $26(12 \%)$ & $187(87 \%)$ & $215(100 \%)$ \\
\hline \multirow[t]{4}{*}{ Access to scholarships } & Poor & $48(86 \%)$ & $6(11 \%)$ & $2(4 \%)$ & $56(26 \%)$ \\
\hline & Moderate & $65(64 \%)$ & $17(17 \%)$ & $20(20 \%)$ & $102(47 \%)$ \\
\hline & Rich & $29(51 \%)$ & $4(7 \%)$ & $24(42 \%)$ & $57(27 \%)$ \\
\hline & Whole & $142(66 \%)$ & $27(13 \%)$ & $46(21 \%)$ & $215(100 \%)$ \\
\hline \multirow[t]{4}{*}{ Additional skills for the family member } & Poor & $51(91 \%)$ & $4(7 \%)$ & $1(2 \%)$ & $56(26 \%)$ \\
\hline & Moderate & $91(89 \%)$ & $10(10 \%)$ & $1(1 \%)$ & $102(47 \%)$ \\
\hline & Rich & $36(63 \%)$ & $15(26 \%)$ & $6(11 \%)$ & $57(27 \%)$ \\
\hline & Whole & $178(83 \%)$ & $29(13 \%)$ & $8(4 \%)$ & $215(100 \%)$ \\
\hline
\end{tabular}

Education for children aged 7-17 years was already high, although access to a scholarship was still difficult. Generally, they had better education than their parents and this condition occurred in almost all households. Children had met the minimum mandatory education level set by the government (i.e. junior high school level). Even some children had reached senior high school and college levels. The community did not have difficulty accessing the school location because Sidodadi already had elementary and junior high schools, even though there was no public junior high school and only a private junior high school but the school already had a good quality education. The location of senior high schools was outside the village, causing not all junior high school graduates to continue their education to high school. Also, the limited money and the lack of guarantee of the ease of getting a decent job for high school graduates was also the reason for the community not to continue their education to senior high school. Therefore, non-formal education was expected to be complementary to the limitations of formal education. However, nonformal education through training and workshop had not been widely obtained by the community. The community needed assistance in technical aspects related to the diversification of livelihood to get out of poverty.

\section{Household poverty distribution}

Sidodadi Village is divided into four hamlets (dusun): Hamlet 1, Hamlet 2, Hamlet 3, and Hamlet 4. The poverty distribution in four hamlets was almost the same (Figure 3). Improvement of health services, infrastructure, and services stimulated the increase in household welfare. However, based on criteria of economic characteristics and knowledge, the community was not yet prosperous (Figure
2). In line with the research conducted by Andrianto et al. (2016), Sidodadi was a village with most of the population having a low economic level.

Table 9 shows that based on the economic characteristic Hamlet 1 had the most number of poor households compared to other hamlets, while Hamlets 3 and 4 had the most number of rich households. In other categories, the percentage index distribution was almost the same between hamlets. Hamlet 1 was adjacent to the mangrove forests and Hamlet 4 was adjacent to WAR Forest Park. The household in Hamlet 1 had primary livelihoods as traders, fishermen, and services (driver and repair shop). Lots of income resources and the access of main streets that close enough to connect Sidodadi with other villages caused the variance of the livelihood. In contrast, most respondents in Hamlets 3 and 4 were farmer in WAR Forest Park.

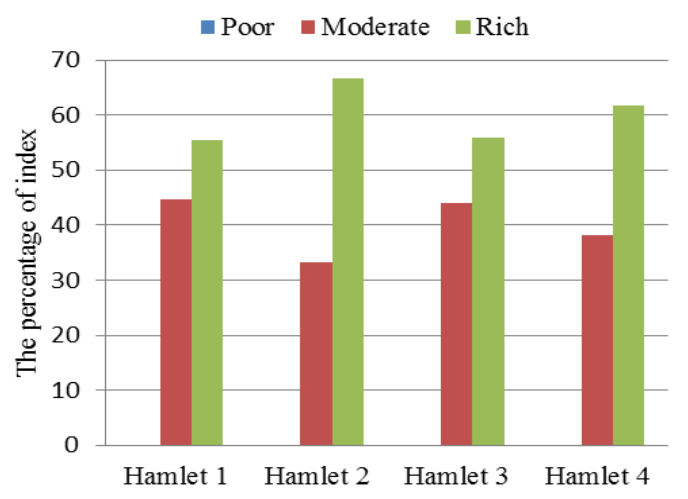

Figure 3. Percentage of wealth/poverty of household in Sidodadi Village, Pesawaran District, Lampung, Indonesia across hamlets 
Table 9. Percentage index of wealth/poverty indicator per hamlet in Sidodadi Village, Teluk Pandan Subdistrict, Pesawaran District, Lampung Province, Indonesia

\begin{tabular}{|c|c|c|c|c|c|c|}
\hline \multirow[b]{2}{*}{ Hamlet } & \multirow{2}{*}{$\begin{array}{l}\text { Household wealth - } \\
\text { category }\end{array}$} & \multicolumn{5}{|c|}{ Indicator } \\
\hline & & $\begin{array}{c}\text { Economic } \\
\text { characteristic }\end{array}$ & $\begin{array}{c}\text { Material } \\
\text { wealth }\end{array}$ & Health & $\begin{array}{l}\text { Infrastructure } \\
\text { and services }\end{array}$ & Knowledge \\
\hline \multirow[t]{3}{*}{ Hamlet 1} & Poor & 41 & 25 & 0 & 0 & 25 \\
\hline & Moderate & 41 & 4 & 13 & 11 & 48 \\
\hline & Rich & 18 & 71 & 88 & 89 & 27 \\
\hline \multirow[t]{3}{*}{ Hamlet 2} & Poor & 23 & 11 & 0 & 0 & 20 \\
\hline & Moderate & 48 & 12 & 21 & 9 & 58 \\
\hline & Rich & 29 & 77 & 79 & 91 & 23 \\
\hline \multirow[t]{3}{*}{ Hamlet 3} & Poor & 25 & 20 & 0 & 2 & 34 \\
\hline & Moderate & 32 & 7 & 14 & 7 & 34 \\
\hline & Rich & 42 & 73 & 86 & 92 & 32 \\
\hline \multirow[t]{3}{*}{ Hamlet 4} & Poor & 26 & 15 & 0 & 0 & 21 \\
\hline & Moderate & 29 & 9 & 21 & 3 & 53 \\
\hline & Rich & 44 & 76 & 79 & 97 & 26 \\
\hline
\end{tabular}

The variety of livelihoods was influenced by the involvement of women (wife) in helping to get additional incomes for her family. Low income was one of the reasons for women's involvement to work as labor. This activity was carried out without ignoring the main task as housewives to take care of their homes and children. The occupation performed by many women in Sidodadi was trading. Some women did trading at home by establishing warung; a part of the house used as a room to sell many kinds of daily needs. Trading in warung can be carried out simultaneously with the home-keeping activities (Rosnita et al. 2014), so the trading does not interfere with the allocation of women's time to perform its primary task as a housewife. Other women did trading in local market or offer their wares around the village. Mostly, this activity conducted by women in Hamlets 1 and 2 which were located close to highways, fish auction warehouse, and schools that provided a great opportunity for trading. On the other hand, farming was undertaken by many women in Hamlets 3 and 4 who depend on forest products. The activities were planting, maintaining, and harvesting of plants that have economic value. Planting was replacing plants that were not productive. Productive plants were fertilized and cleaned of weeds to increase crop yield. Harvesting usually done by women because women were considered more skilled than men. Men who physically stronger will collect the harvest and bring it to the market.

The involvement of woman is needed to improve family welfare. The increased household incomes can be made through the diversification of livelihoods. Family income that previously only relies on one source of livelihood can be increased through additional works (diversification of livelihood) by women (wife). However, women rarely gain access to resources or institutions that can improve their capacity (Handajani et al. 2015). In Sidodadi, women who have non-formal education were less than $20 \%$, in line with the number of working women. Therefore, the role of women in the management of forest resources needed to be improved so the level of the household economy can increase and ease the burden of the head of household in earning a living (Huda 2013).

Figure 4 shows poverty distribution in Sidodadi. Households in Hamlet 3 and 4 which bordering WAR Forest Park had better economic levels than those bordering mangroves. The households utilized WAR Forest Park to meet their living needs. They grew cash crops like banana (Musa spp), cacao (Theobroma cacao) and Multipurpose Trees Species (MPTS). The MPTS planted included coconut (Cocos nucifera), durian (Durio zibethinus), rambutan (Nephelium lappaceum), candlenut (Aleurites moluccana), mango (Mangifera indica), cinnamon (Cinnamomum burmannii), betel nut (Areca catechu), cempaka (Michelia champaca), duku (Lansium domesticum), and avocado (Persea americana) (Qurniati et al. 2017a). When people had free space between cacao and MPTS in their land area, they grew chili (Capsicum sp.), tomato (Solanum lycopersicum), celery (Apium graveolens), lemongrass (Cymbopogon nardus), turmeric (Curcuma longa), and ginger (Zingiberis rhizoma) for daily income. The selected species planted had a quick and continuous production compared to others. However, the poor households only conducted limited farming in the forest because the forest production was sufficient to fulfill the household needs and could not be used as capital for farming development in the forest area. It prompted the household dependency against the forest product caused it did not increase the economic welfare for the households. The main limiting factor for agricultural production was the extent of available land (Trædal and Vedeld 2017). In line with Sidodadi, since the land status was a forest area, the extended and intensive farming activities were not allowed.

WAR Forest Park had increased the economic benefits in the form of cash income rather than in mangrove forests because poor households had limited agricultural land, finance, and human capital. Forest Park was utilized as the source of livelihoods to meet and, if possible, to enhance 


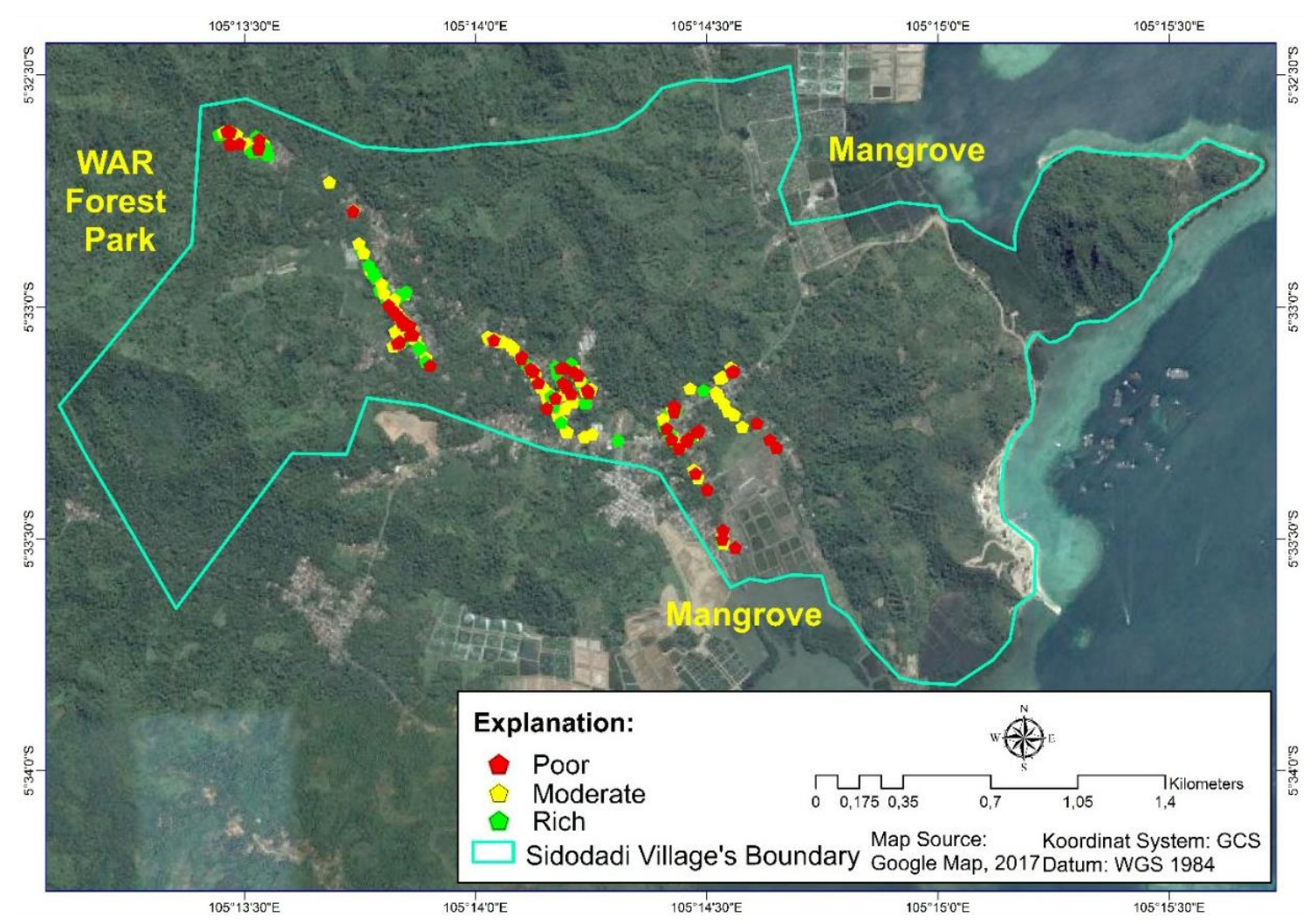

Figure 4. Geographical distribution of household poverty in Sidodadi Village, Teluk Pandan Subdistrict, Pesawaran District, Lampung Province, Indonesia

better livelihood outcomes by growing cash crop and nonwood forest product to meet their subsistence requirements and to sell in markets for cash income. These benefits could not be obtained from mangrove forests because cash crops cannot grow in mangrove forest and utilization of wood forest is prohibited in the mangrove. The mangrove forest in Sidodadi consisted of plant species that relatively homogenous with the dominance of Rhizophora apiculata and Rhizophora mucronata and other species grow in small quantities. Non-wood forest products had not been utilized economically, such as ecotourism which is common utilization of environmental services of mangrove forests. Qurniati et al. (2017b) explained that the utilization of mangrove forests in Sidodadi had limited contribution to additional income for a few people from the wages in planting and mangrove seedling production.

The findings of our study conclude that households around WAR Forest Park have better opportunities of earning income because they can use the forest land in a way that is not obtained from the mangrove forests. Unequal access for households in the utilization of forest resources results in failure to get the opportunity to improve their quality of life, so the sustainable use of forest resources for the community welfare needs to be considered.

\section{ACKNOWLEDGEMENTS}

We extend our gratitude to the University of Lampung for funding this research and Dr. Indra Gumay Febryano for the suggestion on the manuscript.

\section{REFERENCES}

Achmad B, Diniyati D. 2018. The income structure of smallholder forest farmers in rural Sumbawa, Indonesia. Biodiversitas 19 (3): 936-946.

Amir A, Hendrik, Hardiani. 2013. Faktor-faktor yang mempengaruhi kemiskinan dan pengangguran di Kota Jambi. Perspektif Pembiayaan dan Pembangunan Daerah 1: 109-120. [Indonesian]

Andrianto A, Qurniati R, Setiawan A. 2016. Pengaruh karakteristik rumah tangga terhadap tingkat kemiskinan masyarakat sekitar mangrove. Sylva Lestari 4 (3): 107-113. [Indonesian]

Angelsen A. 1997. The poverty-environment thesis: was Brundtland wrong? Forum Develop Stud 1: 135-154.

Angelsen A, Wunder S. 2003. Exploring the forest-poverty link: Key concepts, issues and research implications. CIFOR Occasional Paper No. 40.

Budiharta S, Meijaard E, Wells JA, Abram NK, Wilson KA. 2016. Enhancing feasibility: Incorporating a socio-ecological systems framework into restoration planning. Environ Sci Policy 64: 83-92.

Cahyat A, Gönner C, Haug M. 2007. Assessing household poverty and wellbeing - A manual with examples from Kutai Barat, Indonesia. Center for International Forestry Research (CIFOR), Bogor, Indonesia. 
Cheng SH, Ahlroth S, Onder S, Shyamsundar P, Garside R, Kristjanson, McKinnon M, Miller DC. 2017. What is the evidence for the contribution of forest to poverty alleviation? A systematic map protocol. Environ Evidence 6 (10): 1-11.

Corral S, Díaz AS, Monagas MC, García EC. 2017. Agricultural policies and their impact on poverty reduction in developing countries: Lessons learned from three water basins in Cape Verde. Sustainability 9 (10): 1841.

Embree JF. 1950. Thailand-a loosely structured social system. Am Anthropol New Ser 52 (2): 181-193.

Fadlillah N. 2016. Analisis pengaruh pendapatan per kapita, tingkat pengangguran, IPM dan pertumbuhan penduduk terhadap kemiskinan di Jawa Tengah tahun 2009-2013. Eko-regional 11: 1-9. [Indonesian]

Handajani H, Relawati R, Handayanto E. 2015. Peran gender dalam keluarga nelayan tradisional dan implikasinya pada model pemberdayaan perempuan di Kawasan Pesisir Malang Selatan. J Perempuan Anak 1 (1): 1-21. [Indonesian]

Huda A. 2013. Peran wanita dalam pemberdayaan ekonomi syariah. J Syariah dan Hukum 5 (1): 42-51. [Indonesian]

Jacobus EH, Kindangen P, Walewangko EN. 2018. Analisis faktor-faktor yang mempengaruhi kemiskinan rumah tangga di Sulawesi Utara. J Pembanguan Ekonomi Keuangan Daerah 18 (7): 1-16. [Indonesian]

Johnson FA, Hutton CW, Hornby D, Lazar AN, Mukhopadhyay A. 2016 Is shrimp farming a successful adaptation to salinity intrusion? A geospatial associative analysis of poverty in the populous GangesBrahmaputra-Meghna Delta of Bangladesh. Sustain Sci 11: 423-439.

Kaplale R. 2012. Faktor-faktor yang mempengaruhi tingkat kemiskinan di Kota Ambon (Studi kasus di Dusun Kranjang Desa Waiyame Kecamatan Teluk Ambon dan Desa Waiheru Kecamatan Teluk Ambon Baguala Kota Ambon). Agribisnis Kepulauan 1: 101-115. [Indonesian]

Lin L, Wang W, Gan C, Nguyen QTT. 2019. Credit constraints on farm household welfare in rural China: Evidence from Fujian Province. Sustainability 11 (3221): 1-19.

Machmud J, Imran H, Batalipu R. 2019. Poverty influential factors (faktor yang mempengaruhi kemiskinan). Gorontalo Development Review 2 (1): $23-34$.

Manwa H, Manwa F. 2014. Poverty alleviation through pro-poor tourism The role of Botswana forest reserves. Sustainability 6: 5697-5713.

Mussadun, Nurpratiwi P. 2016. Kajian penyebab kemiskinan masyarakat nelayan di kampung Tambak Lorok. J Perencanaan Wilayah Kota 27 (1): 49-67. [Indonesian]

Nasution A, Rustiadi E, Juanda B, Hadi S. 2015. Two-way causality between social capital and poverty in rural Indonesia. Asian Soc Sci 11 (13): 139-150

Newton P, Miller DC, Augustine M, Byenkya A, Agrawal A. 2016. Who are forest-dependent people? A taxonomy to aid livelihood and landuse decision-making in forested regions. Land Use Pol 57: 388-395.

Nugraha B, Banuwa IS, Widagdo S. 2015. Perencanaan lanskap ekowisata hutan mangrove di Pantai Sari Ringgung Desa Sidodadi Kecamatan Padang Cermin Kabupaten Pesawaran. J Sylva Lestari 2 (3): 53-66. [Indonesian]

Panda S. 2015. Farmer education and household agricultural income in rural India. Int J Soc Econ 42 (6): 514-529.

Pratama YC. 2014. Analisis faktor-faktor yang mempengaruhi kemiskinan di Indonesia. Esensi, J Bisnis Manajemen 4 (2): 210-223. [Indonesian]
Qurniati R, Febryano IG, Zulfiani D. 2017a. How trust influence social capital to support collective action in agroforestry development? Biodiversitas 18 (3): 1201-1206.

Qurniati R, Hidayat W, Kaskoyo H, Firdasari, Inoue M. 2017b. Social capital in mangrove management: A case study in Lampung Province, Indonesia. J Forest Environ Sci 33 (1): 8-21.

Rosnita, Yulida R, Edwina S. 2014. Curahan waktu wanita dan kontribusinya terhadap pendapatan rumah tangga. J Paralella 1 (2): 143-150. [Indonesian]

Santika T, Wilson KA, Budiharta S, Kusworo A, Meijaard E, Law EA, Friedman R, Hutabarat JA, Indrawan TP, St. John, FAV, Struebig MJ. 2019. Heterogeneous impacts of community forestry on forest conservation and poverty alleviation: Evidence from Indonesia. People Nat 2019 (1): 204-219.

Shikuku KM, Winowiecki L, Twyman J, Eitzinger A, Perez JG, Mwongera C, Läderach P. 2017. Smallholder farmers' attitudes and determinants of adaptation to climate risks in East Africa. Clim Risk Manag 16: 234-245.

Simarmata GB, Qurniati R, Kaskoyo H. 2018. Faktor-faktor yang mempengaruhi pemanfaatan lahan Taman Hutan Raya Wan Abdul Rachman. J Sylva Lestari 6 (2): 60-67. [Indonesian]

Spey IK, Kupsch D, Bobo KS, Waltert M, Schwarze S. 2019. The effects of road access on income generation. Evidence from an integrated conservation and development project in Cameroon. Sustainability 11 (3368): 1-14

Suryani E, Permadi LA, Serif S. 2019. Identifikasi karakteristik dan profil kemiskinan di Pulau Lombok: Basis perumusan intervensi kebijakan. J Sosial Ekonomi Humaniora 5 (1): 27-41. [Indonesian]

Syaf R, Hidayat MS, Achmad E. 2013. Faktor-faktor yang mempengaruhi pendapatan rumah tangga miskin di sekitar Taman Nasional Bukit Dua Belas (Studi kasus desa-desa penyangga TNBD di Kecamatan Maro Sebo Ulu, Kabupaten Batang Hari). Perspektif Pembiayaan dan Pembangunan Daerah 2: 1-10. [Indonesian]

Takata N, Inoue M. 2017. How do swiddeners organize small groups and react to exogenous development? A case study of the Bahau in East Kalimantan, Indonesia. Tropics 26 (3): 83-97.

Tiara AR, Banuwa IS, Qurniati R, Yuwono SB. 2017. Pengaruh kerapatan mangrove terhadap kualitas air sumur di Desa Sidodadi Kabupaten Pesawaran. J Hutan Tropis 5 (2): 93-98. [Indonesian]

Trædal LT, Vedeld PO. 2017. Livelihoods and land use in environmental policy approach: The case of PES and REDD+ in the Lam Dong Province of Vietnam. Forests 8 (39): 1-20.

Withaningsih S, Parikesit, Iskandar J, Putri. 2019. Socio-ecological perspective of local bio-resources based production system of palm sugar and palm flour from aren (Arenga pinnata): Case study of Sukaresmi Village, West Bandung, Indonesia. Biodiversitas 20 (7): 1990-1997.

Wu X, Qi X, Yang S, Ye C, Sun B. 2019. Research on the intergenerational transmission of poverty in rural China based on sustainable livelihood analysis framework: A case study of six poverty-stricken counties. Sustainability 2019 (11): 2341.

Zada M, Shah SJ, Yukun C, Rauf T, Khan N, Shah SAA. 2019. Impact of small-to-medium size forest enterprises on rural livelihood: Evidence from Khyber-Pakhtunkhwa, Pakistan. Sustainability 2019 (11): 1-17. 